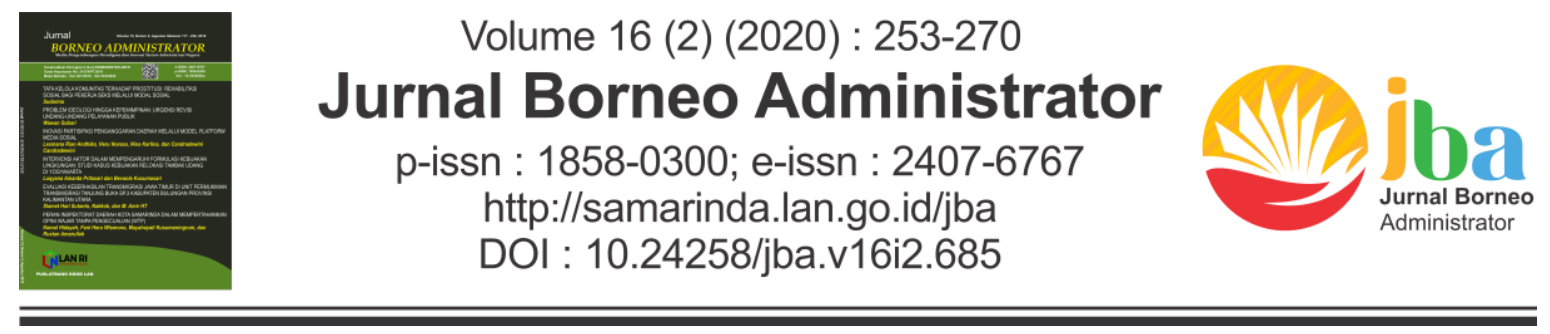

\title{
ANALISIS KEBIJAKAN PENANGANAN WABAH COVID-19: PENGALAMAN INDONESIA
}

\section{ANAL YSIS OF COVID-19 OUTBREAK HANDLING POLICY: THE EXPERIENCE OF INDONESIA}

\author{
Leo Agustino \\ Program Studi IImu Administrasi Publik \\ Fakultas IImu sosial dan IImu Politik Universitas Sultan Ageng Tirtayasa \\ Jl. Raya-Jakarta KM.4, Pakupatan, Banten \\ Email: leo.agustino@untirta.ac.id
}

Naskah diterima: 24 April 2020; revisi terakhir: 3 Agustus 2020; disetujui: 15 Agustus 2020

How to Cite: Agustino, Leo. (2020). Analisis Kebijakan Penanganan Wabah Covid-19: Pengalaman Indonesia. Jurnal Borneo Administrator, 16 (2), 253-270. https://doi.org/10.24258/jba.v16i2.685

\begin{abstract}
This article discusses the efforts of the Indonesian Government in handling the outbreak of Corona Virus Disease-19 (COVID-19). The handling strategies assessed by understanding the efforts, steps, and policies formulated and implemented by the government while the analysis used a deliberative policy analysis approach was used. This approach analyzes the narratives and arguments of the authorities to understand the decision making and policy implementation. The research used a qualitative approach by utilizing descriptive analysis methods. Then the data collection technique used literature studies. The findings found that, first, negative narratives and the slow response of the government. Before COVID-19 approached Indonesia, narratives delivered by the elite government showed that there was no sense of crisis so that it slow-down decision making. Second, weak coordination, especially between the central government and regional governments. This asynchronous coordination created uncertain handling for the control of Coronavirus. Third, citizen ignorance or disobey government instruction. The impact is, the handling effort has stalled because it is not supported by the wider community. The combination of these three factors complicates the government's efforts to control the outbreak of COVID-19 in Indonesia.
\end{abstract}

Keywords: Indonesia, COVID-19, Coronavirus, Handling, Policy

\begin{abstract}
Abstrak
Artikel ini mendiskusikan mengenai upaya Pemerintah Indonesia dalam menangani kasus penyebaran virus korona (Corona Virus Disease-19 (COVID-19). Dengan memahami upaya, langkah, dan kebijakan yang diformulasi dan diimplementasikan oleh pemerintah maka dapat dinilai strategi penanganan tersebut. Untuk menganalisis kasus ini, pendekatan deliberative policy analysis digunakan. Pendekatan ini
\end{abstract}


menganalisis narasi dan argumentasi pihak berwenang untuk memahami pembuatan keputusan dan pelaksanaan kebijakan. Penulisan artikel ini menggunakan pendekatan kualitatif dengan memanfaatkan metode deskriptif analisis. Sementara itu, teknik pengumpulan data yang digunakan adalah studi kepustakaan yang memanfaatkan buku, artikel jurnal, surat kabar, berita online, serta website lembaga-lembaga otoritatif. Temuan penting dari tulisan ini adalah, pertama, narasi negatif dan lambannya respons pemerintah atas penyebaran COVID-19. Narasi-narasi yang disampaikan oleh elite politik sebelum COVID-19 masuk ke Indonesia menunjukkan nihilnya perasaan adanya krisis (sense of crisis) yang mengancam sehingga memperlambat pengambilan keputusan. Kedua, lemahnya koordinasi antar-stakeholder, khususnya antara pemerintah pusat dan pemerintah daerah. Ketidaksinkronan koordinasi ini mengakibatkan pengendalian virus korona menjadi terkatung-katung. Ketiga, ketidakacuhan atau ketidakpatuhan warga atas himbauan pemerintah. Impaknya, upaya penanganan menjadi tersendat karena tidak didukung oleh masyarakat luas. Kombinasi dari ketiga faktor inilah yang memperumit upaya pemerintah untuk mengendalikan penyebaran COVID-19 di Indonesia.

Kata Kunci: Indonesia, COVID-19, Virus Korona, Penanganan, Kebijakan

\section{A. PENDAHULUAN}

Sejak Januari 2020, Corona Virus Disease-19 (COVID-19) telah menginfeksi lebih dari 2.245.872 jiwa di seluruh dunia (WHO, 2020). Lebih dari 152.000 orang telah terkonfirmasi meninggal dunia karena virus ini (WHO, 2020). Oleh karena itu, tidak heran apabila pemimpin-pemimpin pemerintahan di banyak negara berjuang untuk keluar dari wabah COVID-19 dengan pendekatannya masing-masing. Di China, misalnya, pemerintah merespons wabah Covid-19 dengan menyediakan fasilitas kesehatan khusus pasien virus korona, mengubah gedung olahraga, aula, sekolah, dan juga hotel menjadi rumah sakit sementara, melalukan rapid-test ataupun polymerase chain reaction (PCR) pada banyak warga, hingga mengimplementasikan metode mengisolasi kota (lockdown) (Aida, 2020a: 12). Di Daegu, Korea Selatan, pendeteksian dini melalui rapid test dilakukan secara massal dengan tujuan melokalisasi individu yang terpapar Covid-19 sebagai upaya preventif untuk meminimalkan penyebaran virus korona, meliburkan sekolah dan kampus, dan juga melaksanakan lockdown (Park, 2020).

Hal itu juga berlaku bagi pemimpin-pemimpin di negara Asia Tenggara. Satu yang pasti, beberapa negara telah menangani wabah lebih baik daripada pemerintah yang lain adalah suatu hal yang tidak dapat dimungkiri. Vietnam sebagai contoh, telah banyak dipuji (termasuk oleh WHO) atas reaksi dan penanganan mereka dalam menghadapi COVID-19 (Humphrey \& Pham, 2020). Sebaliknya, Myanmar mengabaikan penyebaran virus ini, ketika diketahui virus telah menyebar, Pemerintah Myanmar menawarkan kebijakan yang tidak efektif dalam menahan penyebarannya (Lintner, 2020). Hal ini pun (kasus di Myanmar) terjadi juga di Indonesia.

Indonesia adalah negara dengan populasi terbesar keempat di dunia, respons Pemerintah Indonesia terhadap krisis sangat lamban dan berpotensi menjadi episentrum dunia setelah Wuhan (Sari, 2020). Kebijakan yang tidak responsif dan keliru tentu membahayakan jutaan rakyat Indonesia. Hal ini tampak, misalnya pada bulan Januari dan Februari 2020, ketika virus itu melumpuhkan beberapa kota di Cina, Korea Selatan, Italia, dan lainnya; beberapa negara mengambil kebijakan untuk menutup migrasi manusia lintas negara. Sebaliknya, Pemerintah Indonesia mengambil kebijakan lain yang berupaya menarik wisatawan dan bisnis dari negara-negara yang tengah menutup negara mereka untuk dikunjungi. 
Selain itu, narasi yang dikembangkan oleh elite politik Indonesia bernuansa meremehkan ganasnya virus korona dan menganggap bahwa virus tersebut dapat dihalau dengan doa. Namun, respons sedikit berubah manakala kasus COVID-19 pertama ditemukan. Sejak saat itu, pemerintah mengadopsi kebijakan dari negara-negara yang relatif berhasil, tetapi menolak kebijakan lockdown yang ketat atas alasan akan melumpuhkan perekonomian negara dan warga. Akibatnya, jumlah kasus yang terinfeksi menjadi melonjak, dari kasus pertama pada 2 Maret, ke 1.500-an kasus pada akhir Maret, dan semakin melonjak menjadi 6.575 kasus pada 20 April 2020 (Gugus Tugas Percepatan Penanganan Covid-19, 2020).

Pertanyaannya sekarang, mengapa kasus infeksi COVID-19 di Indonesia melonjak sangat tinggi? Apakah ada pengaruh dari kebijakan yang sulit diimplementasikan? Ataukah ada faktor lainnya? Artikel ini berasumsi bahwa melonjaknya angka kasus COVID-19 di Indonesia disebabkan oleh lambatnya respons kebijakan pemerintah, lemahnya koordinasi antar-stakeholder, dan ketidakpedulian warga atas himbauan pemerintah. Dalam rangka mengembangkan argumen-argumen guna menjelaskan asumsi di atas, artikel ini berfokus pada metode deliberative policy analysis untuk menganalisis kebijakan serta bagaimana implementasinya berdampak pada penanganan wabah COVID-19 di Indonesia.

\section{B. METODE PENELITIAN}

Artikel ini menggunakan pendekatan kualitatif dengan metode deskriptif analisis. Pendekatan kualitatif dipilih karena kemampuannya untuk mendapatkan pemahaman yang mendalam, autentik, dan mendasar mengenai fenomena yang tengah diamati. Metode deskriptif analisis digunakan atas alasan data dan informasi yang dihimpun menumpukan perhatian pada fenomena atau masalah aktual melalui proses pengumpulan data, penyusunan, pengolahan, dan penarikan kesimpulan. Hasil dari itu semua berupaya untuk mendeskripsikan suatu keadaan empiris yang objektif atas fenomena atau masalah yang sedang dikaji. Sedangkan teknik pengumpulan data yang digunakan adalah studi kepustakaan. Hal ini dilakukan karena keterbatasan untuk mewawancara secara langsung narasumber-narasumber otoritatif pada saat tulisan ini dibuat.

Wabah virus korona dan juga implementasi pelaksanaan pembatasan sosial berskala besar (PSBB) di beberapa kota membuat ruang gerak terbatas sehingga tidak memungkinkan melakukan wawancara secara langsung. Inilah alasan kuat mengapa Penulis hanya menggunakan studi kepustakaan sebagai teknik pengumpulan data. Studi kepustakaan yang dimaksud dalam konteks artikel ini adalah upaya Penulis untuk mencari, mengumpulkan, dan mempelajari bahan tertulis berupa buku, artikel jurnal, berita online (seperti kompas.com, tempo.co, cnnindonesia.com) dan konvensional (seperti harian Kompas), dan website lembaga-lembaga otoritatif (seperti who.int, ourworldindata.org/covid, covid19.go.id) yang berkaitan dengan fenomena dan masalah yang dikaji. Terakhir, teknik analisis data dalam penulisan artikel ini berangkat dari penjelasan Creswell (2014: 254-263) yang menumpukan tekniknya pada pengorganisasian data, pembacaan dan memoing (pembuatan catatan), serta pendeskripsian, pengklarifikasian, serta penafsiran data menjadi kode dan tema.

\section{KERANGKA TEORI}

Analisis kebijakan adalah salah satu metode atau teknik yang digunakan dalam studi kebijakan publik dalam rangka untuk menyediakan informasi serta alternatif pilihan bagi para formulator dalam proses pembuatan kebijakan. Merujuk Dunn (1994: 35), analisis kebijakan adalah, "... an applied social science discipline which uses multiple methods of inquiry and arguments to produce and transform policy-relevant information that may be utilized in political setting to resolve policy problem". Dalam arti lain, kompleksitas masalah 
publik mendorong para pembuat kebijakan untuk mendapatkan informasi seluas-luasnya dengan menggabungkan pengetahuan dengan realitas politik yang ada. Tujuannya agar para formulator dapat menyusun kebijakan yang dapat diimplementasikan sesuai latar belakang masalah, kultur, dan juga kepentingan politik yang tidak tampak. Merujuk definisi Dunn (1994) ini, maka analisis kebijakan merupakan teknik atau metode lebih lanjut dari studi kebijakan. Sebab kebijakan misalnya, kerap diartikan sebagai apa yang pemerintah lakukan ataupun tidak lakukan (Dye, 2013:3). Maknanya, kebijakan adalah tujuan yang dinyatakan secara resmi (oleh pihak berwenang) yang didukung pula oleh sanksi. Tetapi definisi Dye menjadi sempit dari tujuan awal studi kebijakan seperti yang digagas Lasswell.

Lasswell (1971) sebagai tokoh awal pencetus studi kebijakan menjelaskan bahwa studi kebijakan bukan hanya perkara teknis tetapi mengarah pada peran pengetahuan dalam memproses (menyusun dan melaksanakan) kebijakan. Oleh karena itu, studi kebijakan dirancang melampaui berbagai disiplin ilmu, baik ilmu politik, sosiologi, antropologi, administrasi, psikologi, maupun ilmu-ilmu lainnya. Namun malangnya, baik studi kebijakan maupun analisis kebijakan saat ini sebagian besar gagal mengambil pandangan Lasswell tersebut. Analisis kebijakan sebagai contoh, hanya mengambil orientasi empiris yang diarahkan kepada praktik manajerial saja (deLeon \& Vogenbeck, 2007). Akibatnya, analisis kebijakan dianggap kurang berhasil memberikan pengetahuan berorientasi masalah, atau dalam bahasa sederhana, analisis kebijakan gagal menghasilkan pengetahuan yang dapat digunakan (Bilotta et al., 2015).

Namun belakangan, studi kebijakan termasuk di dalamnya memperbaiki dirinya. Oleh sebab itu, saat ini berkembang beberapa varian analisis kebijakan, di antaranya narrative policy analysis (Roe, 1994; Dicke, 2001), dialectical model (Marsh \& Smith, 2000), Typologi Power Stucture (Kriesi et al., 2006), deliberative policy analysis (Fischer, 2007), dan banyak lagi. Narrative policy analysis adalah sebuah metode analisis kebijakan publik yang tidak lagi semata mengolah argumen secara kuantitatif tetapi telah bergerak pada logika dan argumen itu sendiri. Perkembangan ini, bagi studi kebijakan, telah menghasilkan seperangkat pendekatan baru yang menghadirkan alternatif bagi metode analisis kebijakan yang kental dengan model teknokratis dan kuantitatif pada era sebelumnya. Oleh karena itu, menurut Roe (1994: 2) analisis kebijakan naratif adalah, "Stories commonly used in describing and analyzing policy issues are a force in themselves, and must considered explicitly in assessing policy options". Dalam arti kata lain, narasi adalah argumen bagi proses formulasi kebijakan. Karena itulah, narasi perlu didengar dan dikutip dari banyak aktor (sebagai unit analisis) untuk "menstabilkan" argumen yang tengah dibangun (dalam istilah narrative policy analysis disebut similar lines of reasoning) dalam rangka menghadapi kompleksitas masalah-masalah publik (Dicke, 2001).

Marsh \& Smith (2000) mengembangkan dialectical model yang bertujuan untuk menjelaskan secara lebih lanjut mengenai peran aktor, relasi aktor, dan kepentingannya dalam proses formulasi kebijakan. Lebih lanjut, model dialektik Marsh \& Smith (2000) menawarkan penjelasan tentang pola hubungan timbal balik, antara: (i) structure and agency (struktur dan agensi); (ii) network and context (jejaring dan konteks); dan (iii) network and outcome (jejaring dan hasil). Hubungan dialektik ini menjelaskan hubungan yang interaktif antara dua variabel, saling mempengaruhi dan dipengaruhi secara berulang-ulang serta terusmenerus.

Pertama, hubungan dialektik antara structure dengan agency harus dipahami sebagai entitas yang sama-sama memiliki kultur, nilai, kepercayaan, sikap, perilaku, dan kepentingannya masing-masing. Karena adanya kepentingan yang berbeda satu dengan lain sehingga sangat mungkin terjadi persaingan antara struktur dan agensi, dan juga antara 
sesama struktur ataupun sesama agensi. Dalam proses dialektik ini, struktur dan agensi akan terus bernegosiasi guna menemukan titik keseimbangan (kesepakatan) dalam proses kebijakan. Kedua, hubungan dialektik network dan context, dalam hal ini dijelaskan bahwa perubahan kebijakan amat dipengaruhi oleh konteks yang meliputinya, dalam hal ini disebut endogenous factor (merujuk pada perubahan dalam komposisi aktor, hubungan antar-aktor, dan lain sebagainya yang bersifat internal) dan exogenous factor (faktor ekonomi, ideologi, politik, dan pengetahuan yang turut mempengaruhi kebijakan). Terakhir, dialektik antara network dengan outcome yang mencakupi: (i) outcome akan mempengaruhi perubahan keanggotaan aktor kebijakan atau bahkan akan menyeimbangkan sumber-sumber daya yang ada di dalamnya; (ii) outcome akan mempengaruhi struktur sosial yang lebih luas yang boleh jadi akan melemahkan posisi kepentingan para aktor; dan (iii) outcome akan mempengaruhi cara pandang para aktor.

Model lainnya dikembangkan oleh Kriesi et al. (2006) dengan menamakan modelnya sebagai typologi power stucture. Menurut mereka, proses formulasi kebijakan terjadi dalam domain subsistem yang tidak hanya didominasi oleh aktor negara, melainkan ditandai juga dengan adanya interaksi antara publik dan swasta. Berdasarkan atas bentuk hubungan antara negara dan swasta ini, maka Kriesi et al. (2006) menggunakan struktur kekuasaan dalam menjelaskan proses formulasi kebijakan yang terdiri dari (i) distribution of power (distribusi kekuasaan) dan dominant type of interaction (tipe interaksi dominan). Distribution of power menjelaskan mengenai (i) apakah kekuasaan terkonsentrasi kepada satu aktor saja atau koalisi aktor atau (ii) apakah kekuasaan dibagi antara aktor atau koalisi aktor? Selain itu, policy network dalam konteks ini juga membedakan antara pelaku negara dan non-negara ((i) partai politik, (ii) kelompok kepentingan, dan (iii) organisasi nonpemerintah. Kedua, dominant type of interaction menjelaskan relasi antar-aktor dalam proses formulasi kebijakan, yang mengungkapkan dominasi antar-aktor kebijakan, termasuk individu atau kelompok, yang aktual atau potensial.

Sementara itu, deliberative policy analysis adalah metode yang dapat digunakan untuk membahas peran argumen, retorik, dan narasi dalam proses analisis kebijakan (Fischer, 2007). Fokusnya pada empat hal, yakni pertama, technical-analytical discourse, bertujuan untuk memverifikasi efisiensi hasil program yang dijalankan, termasuk efek sekunder atau tak terduga yang muncul dari program yang diimplementasikan. Kedua, contextual discourse, bertujuan untuk menilai kontekstualitas atau relevansi suatu program dengan situasi masalah yang terkait dengan situational validation. Ketiga, system discourse, bertujuan untuk menilai tujuan kebijakan mempunyai nilai instrumental atau kontributif bagi masyarakat secara keseluruhan ataupun tujuan kebijakan mengakibatkan masalah tak terduga yang berkonsekuensi terhadap masyarakat luas. Keempat, ideological discourse, bertujuan menyusun kembali tatanan sosial. Merujuk itu semua, deliberative policy analysis dapat dimaknai sebagai upaya untuk menganalisis kebijakan melalui struktur argumen kebijakan gabungan kompleks antara norma, interpretasi, opini, evaluasi, dan juga fakta. Beberapa scholars lain, menyebut deliberative policy analysis dengan istilah ideas centered approach (Schmidt, 2002; 2017) atau discursive institusionalism (Hope \& Raudla, 2012). Di mana inti dari pendekatan ini menempatkan ide sebagai materi kebijakan dalam latar institusional atau situasional tertentu.

Untuk menganalisis pelaksanaan kebijakan penanganan wabah COVID-19, maka pendekatan Marsh \& Smith (2000) dimanfaatkan dengan mengkombinasikannya dengan pendekatan implementasi Edward III dalam Agustino (2020). Apa yang disampaikan oleh Edward III dalam hal pelaksanaan kebijakan? Pertama, komunikasi, yang mengelaborasi mengenai koordinasi antar-aktor yang jelas dan konsisten. Kedua, struktur birokrasi, 
menempatkan adanya standar pelaksanaan yang jelas mengenai pelbagai hal (dalam hal ini protokol penanganan COVID-19). Ketiga, sumber daya, yang menumpukan perhatian pada kompetensi dan kapabilitas para pelaksana, pemanfaatan informasi, wewenang, serta fasilitas. Terakhir, keempat, disposisi, yang terdiri dari insentif, pengaturan birokrasi (staffing the bureucracy), dan sikap pelaksana. Pendekatan dialectical model Marsh \& Smith (2000) yang terdiri dari: (i) structure and agency, (ii) network dan context, dan (iii) network and outcome apabila dianalisis, maka akan setarikan nafas dengan pendekatan Edward III yang menumpukan perhatian pada empat hal: (i) komunikasi, (ii) struktur birokrasi, (iii) sumber daya, dan (iv) disposisi. Structure and agency berimpitan dengan struktur birokrasi, sumber daya, dan disposisi dalam pemahaman Edward III; sementara itu, network and context lebih mengarah pada keempat hal yang disampaikan Edward III; demikian pula dengan network and outcome. Merujuk pada kedua pendekatan tersebut, analisis kebijakan penanganan wabah COVID-19 dalam artikel ini mengarah pada (i) narasi negatif dan lambannya respons pemerintah (struktur, agensi, dan konteks), (ii) lemahnya koordinasi antar-stakeholders (komunikasi dan network), dan (iii) ketidakacuhan warga (konteks).

Sementara itu, pembahasan mengenai COVID-19 di Indonesia masih sangat sedikit, terutama dalam konteks kebijakan. Oleh karena itu, tulisan ini berupaya untuk mengisi kekosongan tersebut. Meskipun kajian dan artikel mengenai COVID-19 masih sedikit, tetapi tetap ada dan uraiannya lebih banyak mengarah pada konteks kesehatan, yang di antaranya ditulis Susilo et al., (2020) dan Yuliana (2020). Keduanya membahas COVID-19 dari sisi literatur kesehatan. Lain dari itu, pada kajian dalam studi sosial dan politik, perbincangan mengenai COVID-19 dielaborasi juga oleh kumpulan akademisi dari Universitas Gadjah Mada (UGM) dalam buku yang bertajuk "Tata Kelola Penanganan COVID-19 di Indonesia: Kajian Awal" (Mas'udi \& Winanti, 2020). Mereka mengelaborasi empat isu menarik, yaitu (i) kegamangan negara dan lembaga internasional dalam merespons COVID-19, (ii) respons dan resiliensi sektoral, (iii) kelompok marginal dan modal sosial di era COVID-19, dan (iv) dimensi pengetahuan dan komunikasi publik COVID-19. Sedangkan dalam konteks lain, seperti kesiapan pemerintah daerah (Dzakwan, 2020), kebijakan pangan (Hirawan \& Verselita, 2020), penundaan pilkada. Namun, uraian artikel ini berbeda dengan tulisantulisan tersebut di atas. Perbedaannya terletak pada narasi kebijakan yang disampaikan oleh elite politik terkait COVID-19, koordinasi antarpemangku kepentingan dalam menerapkan kebijakan yang telah ditetapkan, dan wujudnya ketidakpatuhan warga atas instruksi (atau kebijakan) pemerintah.

\section{HASIL DAN PEMBAHASAN}

\section{Narasi Negatif dan Lambannya Respons Pemerintah}

Awal tahun 2020, masyarakat dunia dikejutkan oleh wabah COVID-19 yang menewaskan banyak orang di Kota Wuhan, Provinsi Hubei, China. Beberapa negara langsung merespons penyebaran virus yang mematikan itu dengan pelbagai caranya masingmasing. Ada yang menutup jalur migrasi manusia dari dan ke China, melakukan karantina pada orang-orang yang baru kembali bepergian dari China, hingga melakukan rapid-test sebagai bentuk antisipasi penyebaran. Malangnya, Pemerintah Indonesia kurang tanggap atas masifnya penyebaran COVID-19 yang menggandakan diri dengan menginfeksi sebanyak mungkin orang. Meski virus ini tidak seganas dan semematikan sindrom pernapasan akut parah (Severe Acute Respiratory Syndrome, SARS), tetapi COVID-19 menyerang lebih banyak orang dengan total kematian beratus kali lipat. 
Ketika masyarakat dunia sedang sibuk mengantisipasi penyebaran wabah virus korona, pemerintah Indonesia justru tidak menyiapkan apa-apa untuk menghadapi dan mengendalikan penyebaran COVID-19. Pemerintah cenderung menganggap remeh hal tersebut. Ini misalnya tampak dari narasi yang disampaikan oleh Menteri Kesehatan pada pertengahan Januari yang menyatakan, "Masyarakat tidak perlu panik soal penyebaran virus korona, enjoy saja" (Satria 2020). Sementara itu, beberapa hari kemudian, pada awal Februari, Menteri Koordinator bidang Politik, Hukum dan Keamanan (Menko Polhukam) mengklaim bahwa Indonesia merupakan satu-satunya negara besar di Asia yang belum memiliki kasus positif virus korona (cnnindonesia, 2020). Narasi-narasi tersebut menunjukkan ketidaktanggapan Pemerintah Indonesia dalam menghadapi pandemi COVID19 yang pada saat itu sudah menyebar ke banyak negara. Sekaligus juga menggambarkan lemahnya daya antisipatif dan adaptif struktur birokrasi Pemerintah Indonesia dalam menghadapi masalah kesehatan. Ketidakmampuan birokrasi untuk menanggapi perubahan yang begitu cepat dalam hal kesehatan mendorong kebingungan para elite politik yang sekaligus juga perumus kebijakan untuk menetapkan kebijakan yang sesuai dengan situasi dan kondisi yang terjadi. Akibatnya, justru narasi-narasi negatif yang muncul dibanding narasi bersifat positif dan implementatif dalam hal pandemik COVID-19.

Nahasnya lagi memang, sampai pertengahan Februari, tidak ada satu pun kebijakan yang diambil oleh Pemerintah Indonesia untuk menghadapi COVID-19. Bahkan pada saat seorang profesor epidemiologi dari Harvard T.H. Chan School of Public Health (Harvard University), Profesor Marc Lipsitch, menyatakan bahwa sangat mungkin virus korona telah tersebar di Indonesia, tidak ada satu pun yang menganggapnya serius. Lebih lanjut, menurut Profesor Lipsitch, Pemerintah Indonesia telah gagal untuk mendeteksi kehadiran COVID19 di Indonesia (Aida, 2020b: 1). Penjelasannya tersebut didasarkan atas penelitiannya terkait jumlah rerata penumpang dari China seluruh dunia yang tidak sedikit, termasuk ke Indonesia. Namun, pernyataan Profesor Lipsitch ditentang oleh Menteri Kesehatan, bahkan ia menantang asumsi Profesor Lipsitch untuk membuktikan langsung hasil riset yang memprediksi virus korona semestinya sudah masuk ke Indonesia.

Narasi-narasi negatif juga disampaikan oleh Menteri Koordinator Perekonomian (Menko Perekonomian) meski dalam konteks berkelakar yang menyatakan, "Karena perizinan di Indonesia berbelit-belit, maka virus korona pun tak bisa masuk (Penulis: ke Indonesia)" (Garjito \& Aditya, 2020). Menteri Perhubungan menyampaikan kelakarnya yang lain di tempat berbeda, dengan menyatakan bahwa bangsa Indonesia kebal virus korona karena doyan nasi kucing (Saubani, 2020). Ini semua menunjukkan perilaku elite pemerintah yang antisains, padahal beberapa waktu sebelumnya World Health Organization (WHO) telah mendeklarasikan COVID-19 sebagai epidemi dunia. Untuk mengantisipasi hal tersebut World Health Organization (2020) menerbitkan panduan strategis dalam menghadapi infeksi virus tersebut dengan tajuk "2019 Novel Coronavirus (2019-nCoV): Strategic Preparedness and Reponse Plan". Atas kesadaran inilah banyak negara menyikapi secara serius untuk meminimalkan dan sedapat mungkin menghentikan penyebaran virus yang mematikan tersebut. Malangnya, tidak dengan Indonesia, terutama di awal-awalnya.

Perilaku antisains tersebut menjelaskan bahwa Pemerintah Indonesia belum memahami context COVID-19 sebagai epidemi yang mematikan. Impaknya, narasi dan komunikasi antisains lebih sering muncul berbanding narasi yang mengarah pada formulasi kebijakan yang sesuai untuk menyelesaikan masalah virus korona. Hal ini juga tampak pada pernyataan Wakil Presiden Indonesia yang menyatakan salah satu penyebab kenapa virus korona tidak masuk ke Indonesia adalah berkat doa ulama yang selalu membaca doa Qunut 
(Maranda, 2020). Narasi wakil presiden dan narasi-narasi "wakil pemerintah" menunjukkan nihilnya sense of crisis dari para pimpinan bangsa sehingga memperlambat perumusan kebijakan yang bersifat strategis.

Ketidaktanggapan Pemerintah Indonesia juga ditunjukkan dengan rencana mengucurkan dana untuk media dan influencer dalam rangka promosi wisata. Insentif untuk wisatawan mancanegara yang dianggarkan oleh Pemerintah Indonesia sebesar Rp298,5 Miliar, dengan perincian: subsidi diskon tiket pesawat Rp98,5 Miliar, anggaran promosi Rp103 Miliar, kegiatan kepariwisataan sebesar Rp25 Miliar, dan jasa influencer sebesar Rp72 Miliar (Sani, 2020: 1). Anggaran sebesar Rp72 Miliar ini diarahkan untuk menangkal ketakutan masyarakat terhadap COVID-19 dalam dunia maya. Di sisi lain, insentif pemerintah tersebut ditujukan untuk menarik wisatawan mancanegara yang tidak dapat berwisata ke negara-negara yang telah melakukan lockdown sehingga Pemerintah Indonesia menganggapnya sebagai peluang dalam meningkatkan kunjungan wisata ke Indonesia. Langkah ini tentu menjadi bumerang bagi pemerintah karena bukan hanya mendapat kritik luas, tetapi juga menunjukkan ketiadaan prioritas pemerintah dalam menangkal penyebaran COVID-19.

Manakala Pemerintah Indonesia mengonfirmasi kasus pertama COVID-19 pada 2 Maret 2020, barulah beberapa strategi dan kebijakan diambil. Namun, hal tersebut sudah terlambat. Beberapa kebijakan tersebut meliputi melarang semua penerbangan dari dan ke China; menghentikan pemberian visa bagi warga negara China untuk melakukan perjalanan ke Indonesia; membatasi perjalanan dari dan ke beberapa negara seperti Korea Selatan, Italia, dan Iran; meliburkan sekolah, kampus, termasuk beberapa kantor pemerintahan dan perusahaan swasta; hingga menutup pusat-pusat hiburan. Mereplikasi kebijakan dari negaranegara yang berhasil "meratakan kurva" dilakukan oleh Pemerintah Indonesia guna mengendalikan luasan penyebaran COVID-19. Upaya replikasi kebijakan ini diambil oleh Pemerintah Indonesia sebagai bentuk sensitifitas pemerintah pada kebijakan-kebijakan yang sudah diformulasi dan diimplementasikan dan dianggap berhasil oleh negara-negara lain. Sementara itu, di sisi kesehatan, Pemerintah Indonesia menyediakan alat pelindung diri (APD), masker, obat-obatan, mengalihfungsikan beberapa hotel dan gedung pertemuan menjadi rumah sakit khusus penanganan COVID-19. Pemerintah Indonesia juga mengoptimalkan tes COVID-19, baik melalui rapid test maupun melalui PCR. Tujuannya agar sebaran virus korona dapat dilokalisasi agar pemerintah memiliki peta sebaran COVID19 melalui hasil tes tersebut. Namun, memang angka tes COVID-19 di Indonesia terlalu sedikit jika dibandingkan dengan negara-negara di Asia Tenggara lainnya (lihat Gambar 1).

Kebijakan-kebijakan tersebut diambil karena Pemerintah Indonesia sadar bahwa wabah COVID-19 merupakan bencana berskala nasional yang harus diselesaikan dengan cara yang luar biasa (extra-ordinary). Oleh sebab itu, tidak heran apabila Presiden Indonesia menerbitkan Keputusan Presiden (Keppres) Nomor 12 Tahun 2020 tentang Penetapan Bencana Non-Alam Penyebab Corona Virus Disease 2019 (COVID-19) Sebagai Bencana Nasional pada 13 April 2020, meskipun dalam waktu yang amat terlambat karena jumlah orang yang terinfeksi sudah mencapai 6.760 orang serta 590 orang lainnya meninggal dunia (Gugus Tugas Percepatan Penanganan Covid-19, 2020). Kegagalan menanggulangi penyebaran COVID-19 terlihat sangat jelas ketika Presiden Joko Widodo menunjukkan "kemarahannya" pada para menterinya di Sidang Kabinet Paripurna Perdana yang berlangsung pada tanggal 18 Juni 2020 lalu. Hal ini menjelaskan begitu lambannya respons pemerintah dan negatifnya narasi (komunikasi publik) yang disampaikan oleh elite politik sehingga menciptakan gelombang "tsunami” COVID-19 di Indonesia. Sebab, ketika negaranegara lain berhasil melandaikan kurva penyebaran virus korona, di Indonesia justru terjadi 
peningkatan infeksi virus korona yang sangat tinggi. Hingga 1 Juli 2020 saja (ketika tulisan ini tengah diperbaiki), individu yang terinfeksi atau positif terpapar COVID-19 mencapai 56.385 jiwa (Gugus Tugas Percepatan Penanganan Covid-19, 2020).

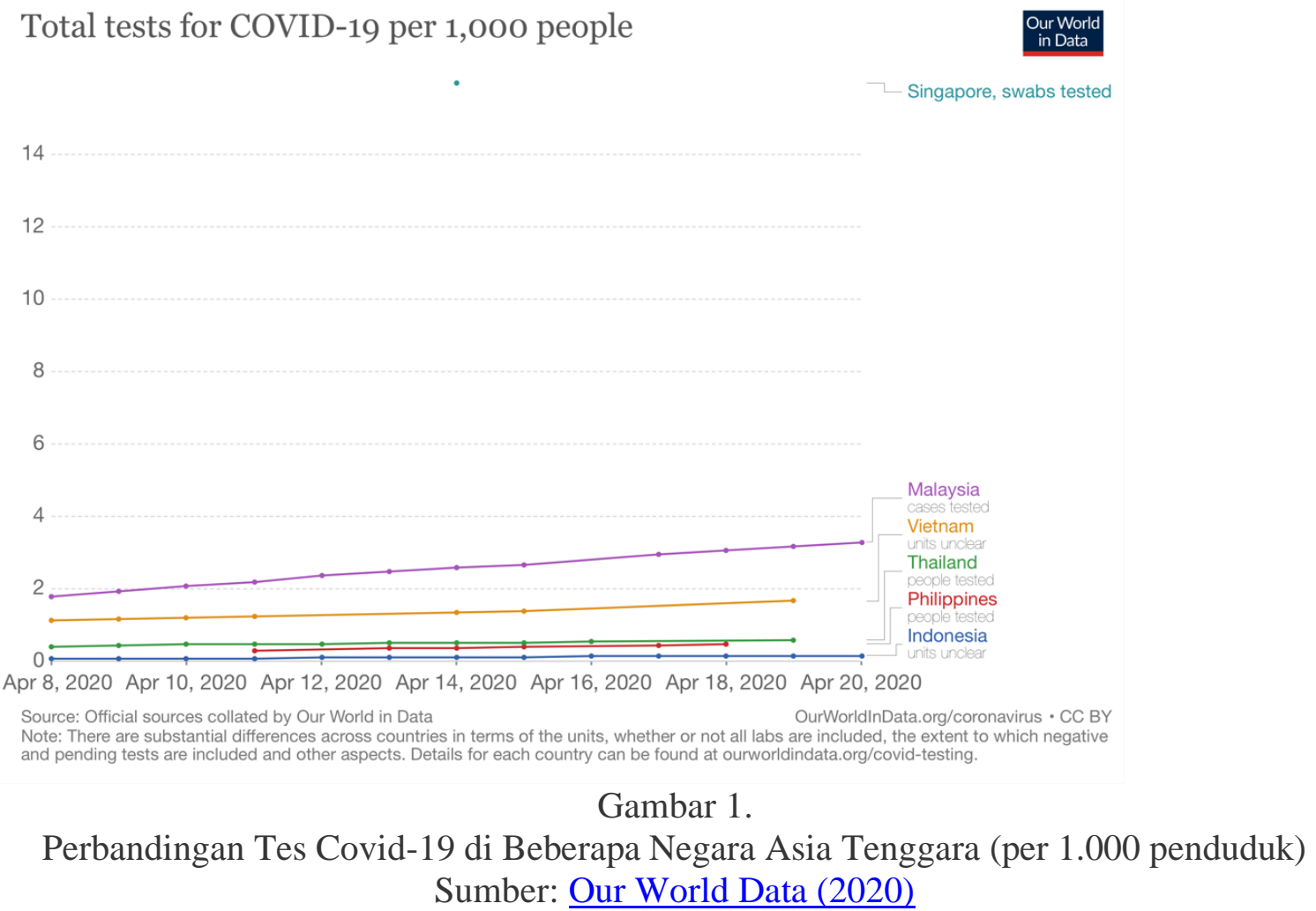

\section{Lemahnya Koordinasi Antar-Stakeholders}

Selain masalah lambatnya pengambilan keputusan dan pembuatan kebijakan yang berimplikasi pada terlambatnya implementasi penanganan COVID-19, lemahnya koordinasi antar pemangku kepentingan pun menjadi problem dalam mengendalikan penyebaran virus korona di Indonesia. Hal ini terjadi karena sistem negara kesatuan menempatkan pemerintah pusat sebagai pemangku kepentingan utama dalam hal kebencanaan, baik bencana alam maupun bencana non-alam termasuk kesehatan. Selain bentuk negara kesatuan, dalam sistem politik Indonesia, Indonesia juga mengenal konsep otonomi daerah yang mengamanatkan semua urusan dapat dijalankan oleh pemerintah daerah kecuali, politik luar negeri, pertahanan, keamanan, yustisi, moneter dan fiskal, serta agama. Dan bagi pemerintah daerah, urusan kesehatan adalah urusan yang dapat ditangani oleh mereka; meskipun secara konseptual urusan kesehatan merupakan urusan yang bersifat concurrent yang dapat diurus bersama antara pemerintah pusat, provinsi dan kabupaten/kota. Namun, ketika beberapa pemerintah daerah melakukan langkah proaktif untuk menyampaikan informasi dan sosialisasi mengenai COVID-19 (di awal-awal penyebaran virus Korona), pemerintah pusat mengkritik langkah-langkah proaktif pemerintah daerah tersebut.

Pada 3 Maret 2020, sehari setelah pengumuman "masuknya" kasus COVID-19 di Indonesia, juru bicara pemerintah untuk penanganan virus korona menyatakan kepada semua pihak (dalam hal ini pemerintah daerah) untuk menahan diri menyampaikan informasi mengenai status penularan virus Korona (Nugraheny, 2020:1). Mengapa informasi tersebut harus desentralisasi oleh pemerintah pusat (Kementerian Kesehatan) Sebab pemerintah 
daerah dianggap terlalu mendramatisasi kasus penyebaran COVID-19 di Indonesia. Di samping adanya asumsi pernyataan kepala daerah (yang merepresentasikan pemerintah daerah) tersebut diarahkan untuk meningkatkan popularitas kepala-kepala daerah semata berbanding didasarkan pada argumen dan alasan medis. Ini karena pada tahun 2020 adalah tahun pemilihan kepala daerah (Pilkada) di beberapa provinsi, kota, dan kabupaten di Indonesia. Oleh karena itu, Menteri Dalam Negeri pun unjuk bicara dan meminta para kepala daerah untuk tidak menyampaikan pernyataan yang berpotensi menimbulkan polemik, keresahan, serta kepanikan di masyarakat terkait COVID-19.

Namun pemerintah daerah pun tidak dapat disalahkan begitu saja. Sikap proaktif pemerintah daerah dalam memberikan informasi tersebut didasarkan pada kelambanan pemerintah pusat itu sendiri seperti yang disampaikan pada subbagian ini. Hal ini terkonfirmasi dari lambatnya Radiogram Kementerian Dalam Negeri (Kemendagri) Nomor 443.1/2130/SJ terkait mengantisipasi dan pencegahan terkait isu infeksi Novel Corona Virus (COVID-19) yang disampaikan kepada kepala-kepala daerah di seluruh Indonesia. Radiogram atau instruksi itu sebenarnya telah ditandatangani oleh Menteri Dalam Negeri pada 4 Maret 2020, tetapi malangnya, radiogram tersebut belum dapat didistribusikan karena masih menunggu koordinasi dengan Kementerian Kesehatan. Artinya, pemerintah daerah yang menyampaikan informasi mengenai penyebaran COVID-19 tidak dapat disalahkan karena instruksi belum mereka terima.

Bukan hanya itu, lemahnya komunikasi (meminjam istilah Edward III) dan ketidaksinkronan koordinasi antara pemerintah pusat dan daerah (network yang tidak terkelola secara baik) terjadi juga dalam pelaksanaan kebijakan isolasi wilayah (lockdown) di beberapa daerah. Pada pertengahan Maret 2020, pemerintah pusat sudah memutuskan untuk tidak mengadopsi isolasi wilayah karena akan mengganggu migrasi manusia dan menghambat perekonomian warga. Karena itu, keputusannya adalah menerapkan social atau physical distancing di seluruh wilayah Indonesia. Namun lima daerah (Bali, Papua, Solo, Maluku, dan Tegal) menentang kebijakan pusat dengan menerapkan lockdown dengan skala berbeda-beda.

Kota Tegal, misalnya, wali kotanya secara langsung mengumumkan secara terbuka bahwa daerah di bawah kepemimpinannya akan menerapkan local lockdown dengan cara menutup akses jalan protokol dalam kota dan jalan penghubung antarkampung. Argumen Wali Kota Tegal jelas yakni untuk memutus mata-rantai penyebaran virus korona di wilayahnya. Keputusan tersebut diambil karena tidak ada alternatif kebijakan yang dapat mengendalikan penyebaran COVID-19 yang sangat luas dan masif. Selain itu, tidak adanya arahan yang jelas dari pemerintah pusat untuk mengendalikan virus korona sehingga mendorong pemerintah-pemerintah daerah mengimplementasikan kebijakannya sendiri yang dianggap mampu mengendalikan penyebaran COVID-19 di daerahnya masing-masing. Polemik ini berlangsung beberapa hari setelah melalui komunikasi yang intensif, maka pada akhirnya lima pemerintah daerah tersebut di atas bersetuju dengan instruksi pemerintah pusat untuk tidak melakukan lockdown wilayah.

Lemahnya koordinasi atau komunikasi antar-stakeholder dalam penanganan COVID19 juga terlihat dari adanya pembatasan lokasi pemeriksaan COVID-19 "hanya" di Jakarta yakni di Badan Penelitian dan Pengembangan, Kementerian Kesehatan (Balitbang Kemenkes). Padahal ada puluhan rumah sakit dan laboratorium di daerah yang dapat diberdayakan untuk melakukan pemeriksaan spesimen virus korona. Pemusatan penanganan ini membuat pengambilan keputusan dan tindakan menjadi lamban bukan tanpa dasar. Undang-undang Nomor 6 Tahun 2018 Tentang Kekarantinaan Kesehatan adalah landasannya. Pada Pasal 5 Ayat (1) ditulis, "Pemerintah Pusat bertanggung jawab 
menyelenggarakan Kekarantinaan Kesehatan di Pintu Masuk dan wilayah secara terpadu". Bahkan, lebih lanjut pada Pasal 11 Ayat (1) dituliskan, "Penyelenggaraan Kekarantinaan Kesehatan pada Kedaruratan Kesehatan Masyarakat dilaksanakan oleh Pemerintah Pusat ...." Sementara peran pemerintah daerah dalam regulasi ini menjadi "pengikut" atau dapat berperan aktif apabila "dilibatkan" oleh pemerintah pusat (Pasal 5 Ayat (2). Maknanya, pemeriksaan COVID-19 hanya dapat dilakukan di Jakarta padahal Indonesia memiliki luas wilayah yang sangat luas sehingga dapat dibayangkan betapa banyak waktu yang terbuang hanya untuk proses transportasi logistik spesimen dari daerah ke Jakarta.

Lemahnya koordinasi antarinstansi juga tampak dari lambatnya pengesahan Keputusan Menteri Kesehatan Nomor HK.01.07/MENKES/214/202010 tentang Jejaring Laboratorium Pemeriksaan COVID-19 yang menjadi dasar hukum bagi keterlibatan beberapa laboratorium di seluruh Indonesia untuk melakukan fungsi pemeriksaan. Padahal pemerintah paham betul bahwa hanya mengandalkan Balitbang Kemenkes di Jakarta adalah satu hal absurd. Karena itulah, Menteri Kesehatan memutuskan untuk melibatkan puluhan laboratorium di seantero nusantara untuk melakukan pemeriksaan terhadap spesimen warga dari daerah yang berbeda. Masalahnya, komunikasi dan koordinasi untuk melegalkan kebersamaan beberapa laboratorium dengan Pemerintah Pusat terhambat karena Keputusan Menkes tersebut baru ditandatangani 18 hari setelah pengumuman kasus pertama di Indonesia. Akibatnya, jumlah pasien terpapar COVID-19 melonjak dari 2 kasus menjadi 367 kasus dengan 32 di antaranya meninggal dunia (Gugus Tugas Percepatan Penanganan Covid-19, 2020). Merujuk pada lemahnya networking ini, tidak heran apabila upaya pemerintah dalam pengendalian COVID-19 menjadi tidak optimal.

Dalam konteks komunikasi yang lemah dan koordinasi yang tidak optimal tersebut membuat daya serap anggaran program penanganan COVID-19 menjadi sangat minim. Padahal pemerintah pusat telah menyediakan dana sebesar Rp. 75 Triliun, tapi baru terserap 1,53\%-nya saja (sekitar Rp. 1,14 Triliun). Ini pulalah yang menjadi sebab marahnya Presiden pada Sidang Kabinet Paripurna Perdana di pertengahan Juni 2020 lalu, sekaligus menjadi faktor pendorong menguatnya kembali isu pergantian (reshuffle) kabinet di awal Juli 2020.

Di samping itu, minimnya penyediaan alat pelindung diri (APD) menjadi indikasi begitu lemahnya komunikasi dan koordinasi (networking) antar-lembaga di Indonesia khususnya lembaga yang terkait erat dengan persoalan penanganan COVID-19. Impact paling menyakitkan dari minimnya penyediaan APD oleh pemerintah adalah gugurnya para pahlawan bangsa (baca: dokter dan perawat) di banyak daerah. Hingga 19 April 2020 saja, sudah 29 tenaga kesehatan yang meninggal dunia; angka ini belum termasuk tenaga kesehatan dan perawat yang terinfeksi COVID-19 (Pusparisa, 2020). Menurut keterangan Ikatan Dokter Indonesia (IDI), salah satu penyebab dari banyaknya tenaga kesehatan yang meninggal adalah karena kurangnya APD. Semestinya pemerintah dapat dengan sigap menyediakan APD, khususnya, di rumah-rumah sakit rujukan pasien COVID-19. Atau dalam situasi lain APD justru ditemukan digunakan oleh polisi lalu lintas (Polantas) pada saat tenaga kesehatan, peneliti yang bekerja di dalam biosafety cabinet Level 2, dan perawat membutuhkannya. Sebagai ganti APD yang susah diperoleh, beberapa tenaga kesehatan dan perawat menggunakan jas hujan plastik untuk melindungi dirinya. Kondisi ini direkam oleh Dr. Lee Morgenbesser dari Griffith University yang menyatakan bahwa penanganan virus Korona di Indonesia merupakan penanganan COVID-19 terburuk sehingga memungkinkan penyebarannya menjadi sangat masif dan tak terkendali (Gedoan, 2020). Jika saja komunikasi dan koordinasi antara pelbagai pihak berjalan lancar, maka tenaga kesehatan yang menggunakan "jas hujan plastik" (sebagai pengganti hamzat) tidak akan pernah terjadi. 


\section{Ketidakacuhan Warga Atas Imbauan Pemerintah}

Satu masalah lain yang menyebabkan Indonesia kurang berhasil mengendalikan penyebaran virus korona adalah ketidakacuhan (untuk tidak mengatakan ketidakpedulian) warga terhadap imbauan atau instruksi pemerintah. Masalah ini tampak dari masih ramainya orang-orang berkumpul di kedai-kedai kopi, cafe, mall, bioskop, ataupun tempat-tempat yang telah dilarang oleh pemerintah. Padahal sejak awal pemerintah telah memberikan arahan kepada warga untuk melakukan physical atau social distancing menjaga jarak dengan orang lain. Ini karena penyebaran virus korona, salah satunya adalah, melalui percikan ludah. Jika orang tidak menjaga jarak, dan diketahui bahwa orang yang sedang diajak berbicara terinfeksi atau carrier ("pembawa") virus, maka hal ini sangat berpotensi untuk menularkan kepada orang lain dan menyebarkan lagi pada pihak ketiga, keempat, dan seterusnya. Oleh karena itu, physical atau social distancing adalah salah satu jalan keluar untuk menghambat penyebaran COVID-19. Arahan pemerintah hanya tinggal arahan ketika sebagian besar masyarakat masih juga berimpitan di terminal, stasiun, shelter, pasar, dan lainnya. Warga seolah tidak khawatir dengan virus tersebut karena lebih mementingkan aktivitas harian mereka.

Sama halnya dengan physical atau social distancing, imbauan pemerintah akan penggunaan masker pun tak jarang dilanggar oleh masyarakat luas. Ajakan mencuci tangan setelah keluar rumah juga tidak banyak dituruti oleh warga. Mengapa hal ini bisa terjadi? Melihat pada kondisi di lapangan setidaknya ada tiga kemungkinan mengapa rakyat tidak acuh atas arahan pemerintah.

Pertama, ketidaktahuan warga akan bahaya yang sangat mematikan dari COVID-19. Ketidaktahuan ini disebabkan lemahnya sosialisasi yang dilakukan oleh pemerintah, termasuk pemerintah daerah dan jajarannya. Pemerintah Indonesia tidak optimal mensosialisasikan perlunya hidup bersih dan sehat di antaranya dengan menggunakan masker dan kerap mencuci tangan karena beberapa medium dapat menjadi penghantar penyebaran virus korona. Sebagai contoh, kajian van Doremalem et al. (2020) menjelaskan bahwa virus korona dapat bertahan dalam hitungan jam hingga hari pada medium yang berbeda. Virus korona dapat bertahan beberapa jam di udara, bertahan 4 hingga 8 jam di medium tembaga, bertahan 24 jam di medium kardus, dan juga dapat bertahan hingga 3 hari di medium plastik maupun stainless-steel (van Doremalem et al., 2020: 1). Ketahanan virus inilah yang harus diantisipasi dengan cara hidup bersih dan sehat.

Bagi kelas menengah, yang mendapat informasi dari media-konvensional maupun media-sosial, informasi mudah diperoleh. Dan, mereka memahami bahwa virus ini bisa dinonaktifkan dalam hitungan menit dengan cara menyemprotkan permukaan yang terpapar dengan alkohol atau pemutih rumah tangga. Hal ini sebenarnya sejalan dengan kajian van Doremalem et al. (2020: 1), yang menjelaskan bahwa alkohol dengan kandungan $62-71 \%$, pemutih yang mengandung hidrogen peroksida $0,5 \%$, ataupun pemutih yang mengandung $0,1 \%$ natrium hipoklorit dapat menonaktifkan virus korona. Informasi yang didapat warga ini tidak berasal dari sosialisasi pemerintah, tapi upaya mandiri masyarakat untuk mencari tahu. Akibat ketidaktahuan inilah yang membuat warga masyarakat acuh tak acuh atas imbauan pemerintah karena mereka tidak paham secara mendalam mengenai bahaya mematikan COVID-19.

Kedua, adanya kepentingan untuk memenuhi kebutuhan hidup, mengakibatkan sebagian warga tidak menghiraukan perintah physical atau social distancing. Bahkan ketidakhirauan ini terlihat juga pada saat pelaksanaan Pembatasan Sosial Berskala Besar (PSBB) di beberapa daerah. PSBB adalah kebijakan pemerintah pusat (bekerja sama dengan pemerintah daerah) dalam rangka mengatasi pandemi COVID-19 dengan cara membatasi 
kegiatan tertentu dalam suatu wilayah yang diduga terinfeksi. Larangan itu meliputi kegiatan belajar-mengajar (baik di sekolah maupun kampus), kegiatan keagamaan, resepsi pernikahan, konser, wisata, hingga penggunaan transportasi umum dan pribadi.

Awal-awal implementasi PSBB di Jakarta, Tangerang Raya, Bogor, Depok, dan Bandung Raya menunjukkan penurunan angka migrasi manusia yang cukup signifikan, tetapi beberapa hari kemudian kondisi menjadi relatif sama dengan sebelum awal PSBB. Kajian Aswicahyono (2020) memperkuat hal ini. Satu hal kuat yang menyebabkan warga tidak acuh dengan arahan pemerintah untuk tinggal di dalam rumah (melalui PSBB) disebabkan oleh kebutuhan warga untuk memenuhi kepentingan ekonomi mereka seharihari. Dapat diasumsikan bahwa mereka yang melakukan migrasi adalah para pekerja informal dan mereka yang hidup dari pekerjaan harian. Implikasinya, PSBB hanya menekan migrasi kelas menengah-atas dan atas, sedangkan mereka yang berstatus sosial ekonomi di bawah itu tetap "berjuang" untuk memenuhi kebutuhan hidup sehari-hari.

Ketiga, tiadanya sanksi yang tegas, membuat migrasi manusia tetap tinggi; dan kebijakan physical atau social distancing menjadi kurang berdampak. Misalnya acara Ijtima Jemaah Tabligh Zona Asia 2020 di Kompleks Darul Ulum, Kabupaten Gowa, Provinsi Sulawesi Selatan yang sedianya akan berlangsung empat hari mulai 19 hingga 22 Maret 2020 menjadi salah satu contoh bagaimana sanksi tidak tegas. Ribuan jemaah tabligh dari mancanegara berkumpul di satu lokasi pada saat virus korona mewabah. Meski akhirnya kegiatan itu urung dilaksanakan, tetapi impak dari berkumpulnya ribuan orang mengakibatkan sebaran virus menjadi tidak terkendali. Para jamaah yang pulang dari Gowa didapati terinfeksi dan menularkan virus korona di lingkungan mereka masing-masing (Kurniati, 2020: 1-3). Hal yang sama terjadi juga di Lembang, Kabupaten Bandung Barat, ketika ratusan Jemaah Gereja Bethel Indonesia (GBI) melakukan kegiatan keagamaan di saat COVID-19 mewabah. Dampaknya, ratusan orang terinfeksi dan sebagian di antaranya menjadi pembawa virus ke wilayah lain (Iqbal, 2020). Pada kasus yang lebih mikro pihak berwenang pun tak kuasa untuk memberikan sanksi tegas terhadap para pelanggar physical atau social distancing dan PSBB sehingga orang tidak jera dengan berkumpul serta bermigrasi dalam wilayah ataupun antar-wilayah.

Ketidakpatuhan yang didiskusikan pada subbagian ini sebenarnya mempertegas survei yang dilakukan oleh Ikatan Alumni Fakultas Kesehatan Masyarakat, Universitas Airlangga (Hadi et al., 2020). Survei mereka mendapati bahwa 92,6\% responden aktif berinteraksi di pasar tradisional; 84,1\% di antaranya tidak menggunakan masker serta 89,3\% tidak menerapkan physical atau social distancing. Sementara di supermarket ataupun minimarket tidak jauh berbeda. Dari 97,6\% warga yang aktif ke supermarket ataupun minimarket, $49 \%$ di antaranya tidak menggunakan masker dan 61,7\% tidak mengindahkan instruksi pemerintah untuk melakukan physical atau social distancing. Selain itu, survei ini juga mendapati bahwa sebanyak $81,7 \%$ responden tetap pergi ke masjid, gereja, dan pura; serta $72,5 \%$ responden masih aktif nongkrong atau berkumpul di kafe dan warung kopi.

Isu besar lain yang menjadi kendala bagi Pemerintah Indonesia adalah masalah mudik (mudik adalah singkatan dari mulih ka udik yang berarti pulang ke kampung) lebaran atau Idul Fitri (Eid al-Fitr). Data tahun 2019, ada lebih kurang 23 juta orang melakukan mudik ke pelbagai daerah di Indonesia (Deny, 2019: 1). Pada tahun 2020, lebaran akan jatuh pada 24 Mei dan mudik akan berlangsung 1 minggu sebelum tanggal tersebut. Pada 21 April 2020, Presiden Joko Widodo (juga dikenal dengan sebutan Jokowi) telah mengumumkan mengenai pelarangan mudik. Hal ini tentu akan menimbulkan ketidakacuhan warga lagi karena mudik lebaran adalah budaya yang harus dijalani. Meski larangan mudik lebaran telah dinyatakan pada 21 April 2020, tetapi isu mengenai larangan mudik itu sendiri sudah beredar satu 
minggu sebelumnya. Hal yang merisaukan dari pernyataan presiden tersebut adalah implementasi dari pernyataan presiden tersebut berlaku pada 24 April, atau 3 hari setelah diumumkan. Implikasinya, akan banyak warga yang mencuri start mudik lebaran pada 3 hari tersebut. Merujuk pada artikel Jaya (2020: 6) di harian Kompas kemungkinan jumlah pemudik yang pulang lebih awal hanya dari Jakarta, Bogor, Tangerang, dan Bekasi (Jabodetabek) akan mencapai 2.370 .455 jiwa. Kekhawatiran dari migrasi manusia yang sangat besar itu adalah menyebarnya virus korona ke wilayah-wilayah yang belum terjangkit. Kondisi ini mendorong kenaikan jumlah orang yang terinfeksi COVID-19 yang justru hendak dikendalikan oleh pemerintah meminjam istilah Steven (2020) melakukan "flatten the curve".

Agar larangan mudik dipatuhi, pemerintah memang harus memberi insentif kepada warga dalam berbagai bentuk. Yang sangat mungkin untuk dilakukan adalah memberikan benefit kepada warga yang tidak pulang kampung berupa bantuan langsung dari pemerintah, dapat berupa uang tunai maupun kombinasi antara uang tunai dan bahan kebutuhan harian mereka. Di luar itu semua, tentunya pemerintah tidak lagi hanya menggaungkan himbauanhimbauan, tetapi harus lebih tegas dari apa yang diimplementasikan selama ini. Pemerintah harus berani memberi sanksi hukuman pada warga yang tidak patuh atas imbauan atau arahan pemerintah. Sanksi tersebut bukan hanya membuat orang jera, tetapi juga membuat orang bersetuju (consent) untuk melakukan hal-hal yang dilarang oleh pemerintah.

\section{E. PENUTUP}

Corona Virus Disease-19 (COVID-19) adalah pandemi dunia yang penyebarannya sangat masif. Hingga akhir April sudah lebih dari 2 juta orang terinfeksi virus ini dengan korban meninggal dunia di atas 13 ribu, dan menyebar di 213 negara. Artikel ini menganalisis upaya yang dilakukan oleh Pemerintah Indonesia dalam menangani dan mengendalikan penyebaran COVID-19. Guna mendapatkan data dan informasi, penulis memanfaatkan teknik pengumpulan data studi kepustakaan. Temuan yang diperoleh dari analisis penulis adalah penanganan COVID-19 tidak berjalan maksimal dikarenakan tiga hal penting. Pertama, ketidaktanggapan (hal ini terlihat dari narasi-narasi elite pemerintah yang tampak jauh dari sense of crisis) dan lambannya respons pemerintah sehingga penyebaran virus korona semakin kurang terkendali.

Ketidaktanggapan ini disebabkan oleh lemahnya struktur birokrasi, birokrasi, dan disposisi yang tidak adaptif dengan masalah kesehatan (yang datang dengan gelombang besar) sehingga prioritas pemerintah pada masalah COVID-19 (pada awal-awal penyebaran) terabaikan. Kedua, lemahnya koordinasi antar-stakeholder dalam hal ini pemerintah pusat dan pemerintah daerah menjadi masalah (yang seolah-olah) klasik, tetapi selalu muncul. Masalah "kewenangan urusan" pun tidak luput menjadi perdebatan sengit di awal-awal COVID-19 menyerang Indonesia. Di satu sisi, pemerintah pusat lamban memberikan instruksi terbaik dalam menangani dan mengendalikan penyebaran virus korona. Di sisi lain, pemerintah daerah (yang tidak memiliki wewenang) mengambil langkah sendiri guna menghalau masuk penyebaran virus ini di daerah mereka masing-masing.

Keputusan untuk melibatkan laboratorium dan rumah-rumah sakit daerah pun dirasa sangat lambat. Demikian pula dengan penyediaan APD bagi tenaga kesehatan dan perawat. Akibatnya, puluhan dokter meregang nyawa pada saat membantu pasien-pasien yang terinfeksi COVID-19. Terakhir, ketidakpedulian warga terhadap imbaun pemerintah menjadi faktor ketiga yang mengakibatkan tidak optimalnya penanganan COVID-19 di Indonesia. Keengganan warga menggunakan masker, masih ramainya orang berkumpul di rumah-rumah ibadah, kedai-kedai kopi, restoran, hingga tempat-tempat yang dilarang (oleh 
pemerintah) menjadi penghambat suksesnya social distancing. Selain itu, outcome kebijakan yag diharapkan menjadi jauh "arang dari api" pun sebabkan oleh sebagian besar rakyat Indonesia menggantungkan hidup dari pekerjaan harian yang bersifat ekonomi informal sehingga banyak warga yang tidak patuh terhadap arahan pemerintah.

Kendati demikian, bukan berarti Pemerintah Indonesia tidak melakukan apa-apa. Beberapa langkah direplikasi dari negara-negara yang berhasil menurunkan tingkat penyebaran virus korona, seperti memberlakukan social distancing; menghentikan pembelajaran di sekolah dan kampus dengan menggantinya dengan pembelajaran di rumah; meliburkan dan menutup pabrik, tempat-tempat wisata, mall, kantor swasta, bioskop, dan tempat berkumpul lainnya; melakukan tes COVID-19 baik secara cepat (rapid-test) maupun swab; melaksanakan isolasi terbatas pada wilayah-wilayah yang memiliki tingkat infeksi tinggi dalam bentuk Pembatasan Sosial Berskala Besar (PSBB); mengubahfungsikan hotel maupun gedung-gedung pertemuan menjadi rumah sakit rujukan penanganan virus korona; dan lainnya. Meski begitu, ada beberapa hal yang menurut Penulis belum dilakukan, tetapi penting untuk diimplementasikan, yakni pertama, melakukan pendataan pada warga terpapar dan membuka data tersebut pada publik seluas-luasnya sehingga masyarakat dapat menghindari hubungan atau kontak langsung (untuk sementara waktu) dengan orang-orang yang terinfeksi. Kedua, memperbanyak tes untuk mendeteksi orang-orang yang terinfeksi atau tidak. Ketiga, menambah tenaga kesehatan dan perawat dari daerah-daerah yang tingkat infeksinya rendah ke episentrum COVID-19 sekaligus melindungi mereka dengan cara menyediakan alat pelindung diri (APD) yang lengkap, menambah obat-obatan, peralatan, serta alat kesehatan khusus untuk menangani COVID-19. Keempat, sebagai pilihan terakhir, melakukan micro-lockdown secara ketat dan tegas guna mengendalikan penyebaran virus korona di Indonesia.

\section{DAFTAR PUSTAKA}

Agustino, L. (2020). Dasar-Dasar Kebijakan Publik: Edisi Revisi Ke-2. Bandung: Alfabeta. Aida, N.R. (2020a). Rekap Perkembangan Virus Corona Wuhan dari Waktu ke Waktu. (Kompas Online, 28 Januari 2020). Retrieved from https://www.kompas.com/tren/read/2020/01/28/054600665/rekap-perkembanganvirus-corona-wuhan-dari-waktu-ke-waktu diakses tanggal: 20 April 2020.

Aida, N.R. (2020b). Pernyataan Ahli Harvard, WHO hingga Kemenkes soal Indonesia Negatif Virus Corona. (Kompas Online, 11 Februari 2020). Retrieved from https://www.kompas.com/tren/read/2020/02/11/070000665/pernyataan-ahli-harvardwho-hingga-kemenkes-soal-indonesia-negatif-virus diakses tanggal: 21 April 2020.

Aswicahyono, H. (2020). Keharusan Menekan Mobilitas Penduduk Untuk Mendatarkan Kurva Epidemiologi COVID-19; Bukti Awal dari Data Facebook Disease Prevention Map. 10218(April), 1-4. http://arxiv.org/abs/2003.10218.

Bilotta, G. S., Milner, A. M., \& Boyd, I. L. (2015). How to Increase the Potential Policy Impact of Environmental Science Research. Environmental Sciences Europe, 27(1), 16. https://doi.org/10.1186/s12302-015-0041-X

Creswell, J.W. (2014). Penelitian Kualitatif \& Desain Riset (Edisi 3). Terjemahan. Yogyakarta: Pustaka Pelajar.

deLeon, P., and Vogenbeck, D.M. (2007). The Policy Science at the Crossroads. Dalam Frank Fischer, Gerald J. Miller, and Mara S. Sidney (Eds.). Handbook of Public Policy Analysis: Theory, Politics, and Methods, 3-14. Boca Raton, FL: CRC Press.

Deny, S. (2019). Jumlah Pemudik 2019 Diperkirakan Capai 23 Juta Orang. (Liputan6 $\begin{array}{lllll}\text { Online, } & 20 & \text { Mei } & 2020) . & \text { Retrieved }\end{array}$ 
https://www.liputan6.com/bisnis/read/3971221/jumlah-pemudik-2019-diperkirakancapai-23-juta-orang diakses tanggal: 23 April 2020.

Dicke, W. (2001). Bridges \& Watersheds: A Narrative Analysis of Watermanagement in England, Wales and the Netherlands. Amsterdam: Aksant Academic Publisher.

Dunn, W.N. (1994). Public Policy Analysis: An Introduction $2^{\text {nd }}$ Edition. New Jersey: Prentice-Hall.

Dye, T.R. (2013). Understanding Public Policy 14 ${ }^{\text {th }}$ Edition. New Jersey: Pearson.

Dzakwan, M. H. A. (2020). Memetakan Kesiapan Pemerintah Daerah dalam Menangani COVID-19. CSIS Commentaries, April, 1-11.

Fischer, F. (2007). Deliberative Policy Analysis as Practical Reason: Integrating Empirical and Normative Arguments. Dalam Frank Fischer, Gerald J. Miller, and Mara S. Sidney (Eds.). Handbook of Public Policy Analysis: Theory, Politics, and Methods, 223-236. Boca Raton, FL: CRC Press.

Garjito, D., \& Aditya, R. (2020). Kelakar Menteri Airlangga: Izinnya Berbelit-belit, Virus Corona Tak Masuk. (Suara Online, 15 February 2020). Retrieved from https://www.suara.com/news/2020/02/15/141802/kelakar-menteri-airlangga-izinnyaberbelit-belit-virus-corona-tak-masuk diakses tanggal: 21 April 2020.

Gedoan, R. (2020). Penanganan Virus Corona di Indonesia Dinilai Terburuk. (Zona Utara Online, 24 Maret 2020). Retrieved from https://zonautara.com/2020/03/24/ penanganan -virus-corona-di-indonesia-dinilai-terburuk/ diakses tanggal: 22 April 2020.

Hadi, N, Kukuh SW., Nurita, D., \& Puspitasari, MA. (2020). Pelanggaran Sebabkan Penularan Covid di Jawa Timur Tinggi. (Koran Tempo, 27 Juni 2020). Retrieved from https://koran.tempo.co/read/nasional/454643/pelanggaran-sebabkan-penularan-coviddi-jawa-timur-tinggi diakses 2 Juli 2020.

Hirawan, Fajar B. \& Verselita, A. A. (2020). Kebijakan Pangan di Masa Pandemi COVID19. CSIS Commentaries, April, 1-7.

Hope, M., \& Raudla, R. (2012). Discursive Institutionalism and Policy Stasis in Simple and Compound Polities: The Cases of Estonian Fiscal Policy and United States Climate Change Policy. Policy Studies, 33(5), 399-418. https://doi.org/ 10.1080/01442872.2012.722286

Our World in Data. (2020). Full List Cumulative Total Tests Perthousand. Retrieved from https://ourworldindata.org/grapher/full-list-cumulative-total-tests perthousand?time= 2020408..\&country $=\mathrm{IDN}+\mathrm{MYS}+\mathrm{PHL}+$ Singapore $\% 2 \mathrm{C} \% 20$ swabs\%20tested+THAV NM (diakses tanggal: 21 April 2020).

CNN Indonesia. (2020). Mahfud: RI Satu-satunya Negara Besar di Asia Tak Kena Corona. Retrieved from https://www.cnnindonesia.com/ nasional/20200207194915-20472750/mahfud-ri-satu-satunya-negara-besar-di-asia-tak-kena-corona (diakses tanggal: 21 April 2020).

Gugus Tugas Percepatan Penanganan Covid-19. (2020). Berita. Retrieved from https://www.covid19.go.id (diakses tanggal: 21 April 2020).

Gugus Tugas Percepatan Penanganan Covid-19. (2020). Situasi Virus Corona. Retrieved from https://www.covid19.go.id/situasi-virus-corona/ (diakses tanggal: 20 dan 22 April 2020).

Humprey, C., and Pham, B. (2020). No Deaths: The World Can Learn From Vietnam's Coronavirus Response. (www.dpa-international.com, 13 April 2020). Retrieved from https://www.dpa-international.com/topic/deaths-world-can-learn-vietnamcoronavirus-response-urn\%3Anewsml\%3Adpa.com\%3A20090101\%3A200413-99679250 diakses tanggal: 18 Mei 2020. 
Iqbal, M. (2020). 226 Jemaat Terindikasi Positif Corona, Ini Kata Gereja Bethel. (CNBC $\begin{array}{llllll}\text { Indonesia Online, } & 7 & \text { April } & 2020) . & \text { Retrieved }\end{array}$ https://www.cnbcindonesia.com/news/20200407111620-4-150263/226-jemaatterindikasi-positif-corona-ini-kata-gereja-bethel diakses tanggal: 23 April 2020.

Jaya, Wihana Kirana. (2020). Statistik Mudik di Tengah Pandemi. Kompas, April 18, 2020:6 Kriesi, H., Adam, S., \& Jochum, M. (2006). Comparative analysis of policy networks in Western Europe. Journal of European Public Policy, 13(3), 341-361. https://doi.org/10.1080/13501760500528803

Kurniati, P. (2020). Sederet Fakta Penyebaran Corona dari Klaster Ijtima Ulama Gowa. $\begin{array}{llllll}\text { (Kompas } & \text { Online, } & 20 & \text { April 2020). } & \text { Retrieved }\end{array}$ https://regional.kompas.com/read/2020/04/20/06200001/sederet-fakta-penyebarancorona-dari-klaster-ijtima-ulama-gowa diakses tanggal: 23 April 2020.

Lasswell, H.D. (1971). Pre-View of Policy Science. New York: American Elsevier.

Lintner, B. (2020). Myanmar in denial with zero Covid-19 case claim. (Asia Times Online, 23 Maret 2020). Retrieved from https://asiatimes.com/2020/03/myanmar-in-denialwith-zero-covid-19-case-claim/ diakses tanggal: 20 April 2020.

Maranda, S. (2020). Indonesia Terhindar Virus Corona, Ma'ruf Amin: Berkah Doa Qunut. (Tempo Online, $27 \quad$ Februari 2020). Retrieved from https://bisnis.tempo.co/read/1312785/indonesia-terhindar-virus-corona-maruf-aminberkah-doa-qunut diakses tanggal: 22 April 2020.

Marsh, D., \& Smith, M. (2000). Understanding Policy Networks: Towards a Dialectical Approach. Political Studies, 48(1), 4-21. https://doi.org/10.1111/1467-9248.00247

Mas'udi, Wawan; Winanti, P. S. (2020). Tata Kelola Penanganan COVID-19 di Indonesia: Kajian Awal. Yogyakarta; Gadjah Mada University Press.

Nugraheny, D.E. (2020). Pihak Selain Kemenkes dan Medis Diminta Tak Umumkan Status Penularan Virus Corona. (Kompas Online, 3 Maret 2020). Retrieved from https://nasional.kompas.com/read/2020/03/03/18403351/pihak-selain-kemenkes-danmedis-diminta-tak-umumkan-status-penularan-virus diakses tanggal: 22 April 2020.

Park, S.N. (2020). Cults and Conservatives Spread Coronavirus in South Korea Seoul seemed to have the virus under control. But religion and politics have derailed plans. (Foreign Policy Online, 27 Februari 2020). Retrieved from https://foreignpolicy.com/2020/02/27/coronavirus-south-korea-cults-conservativeschina/ diakses tanggal: 20 April 2020.

Pusparisa, Y. (2020). Dokter Meninggal dalam Pandemi Covid-19. (KataData Online, 21 April 2020). Retrieved from https://databoks.katadata.co.id/datapublish/2020/04/21/ puluhan-dokter-meninggal-dalam-pandemi-covid-19 diakses tanggal: 22 April 2020.

Roe, Emery. (1994). Narrative Policy Analysis: Theory and Practice. Durham: Duke University Press.

Sani, A.F.I. (2020). Genjot Pariwisata, Pemerintah Anggarkan Rp 72 M untuk Influencer. (Tempo Online, 25 Februari 2020). Retrieved from https://bisnis.tempo.co/read/1312156/genjot-pariwisata-pemerintah-anggarkan-rp-72m-untuk-influencer diakses tanggal: 21 April 2020.

Sari, H.P. (2020). Indonesia Disebut Berpotensi Jadi Episentrum Baru Covid-19, Ini Respons Jubir Pemerintah. (Kompas Online, 11 April 2020). Retrieved from https://nasional.kompas.com/read/2020/04/11/20351811/indonesia-disebutberpotensi -jadi-episentrum-baru-covid-19-ini-respons-jubir diakses tanggal: 20 April 2020.

Satria, J.N. (2020). Minta Masyarakat Tak Panik soal Penyebaran Virus Corona, Menkes: Enjoy Saja. (Detik Online, 27 Januari 2020). Retrieved from 
https://news.detik.com/berita/d-4874858/minta-masyarakat-tak-panik-soalpenyebaran-virus-corona-menkes-enjoy-saja diakses tanggal: 21 April 2020.

Saubani, A. (2020). Kelakar Menhub: Kita Kebal Corona karena Doyan Nasi Kucing. (Republika Online, $17 \quad$ Februari 2020). $\quad$ Retrieved from https://republika.co.id/berita/q5ul4k409/kelakar-menhub-kita-kebal-corona-karenadoyan-nasi-kucing diakses tanggal: 21 April 2020.

Schmidt, V.A. (2002). Does Discourse Matter in the Politics of Welfare State Adjusment? $\begin{array}{lllll}\text { Comparative } & \text { Political } & \text { Studies, } & 35(2), & 168-193 .\end{array}$ https://doi.org/10.1177/0010414002035002002

Schmidt, V. A. (2017). Theorizing Ideas and Discourse in Political Science: Intersubjectivity, Neo-Institutionalisms, and the Power of Ideas. Critical Review, 29(2), 248-263. https://doi.org/10.1080/08913811.2017.1366665

Steven, H. (2020). Why Outbreaks Like Coronavirus Spread Exponentially, and How to "Flatten the Curve." (The Washington Post Online, 14 Maret 2020). Retrieved from https://www.washingtonpost.com/graphics/2020/world/corona-simulator/ diakses tanggal: 10 April 2020).

Susilo, A., Rumende, C.M., Pitoyo, C.W., Santoso, W.D., Yulianti, M., Sinto, R., Singh, G., Nainggolan, L., Nelwan, E.J., Khie, L., Widhani, A., Wijaya, E., Wicaksana, B., Maksum, M., Annisa, F., Jasirwan, C.O.M., \& Yunihastuti, E. (2020). Coronavirus Disease 2019: Tinjauan Literatur Terkini. Jurnal Penyakit Dalam Indonesia, 7(1), 45$\underline{67 .}$

van Doremalem, N., Bushmaker, T., Morris, D.H., Holbrook, M. G., Gamble, A., Williamson, B. N., Tamin, A., Harcourt, J.L., Thornburg, N.J., Gerber, S.I., LloydSmith, J.O., de Wit, E., \& Munster, V.J. (2020). Aerosol and Surface Stability of SARSCoV-2 as Compared with SARS-CoV-1. The New England Journal of Medicine, April $15,1-3$.

World Health Organization. (2020). 2019 Novel Coronavirus (2019-nCoV): Strategic Preparedness and Response Plan. February, 28. Retrieved from https://www.who.int/publications-detail/strategic-preparedness-and-response-planfor-the-new-coronavirus

Yuliana. (2020). Corona Virus Diseases (Covid-19); Sebuah Tinjauan Literatur. Wellness and Healthy Magazine, 2(1), 187-192. https://wellness.journalpress.id/wellness/article/view/v1i218wh 